The Journal of Society and Media, April 2021, Vol. 5(1) 119-128

https://journal.unesa.ac.id/index.php/jsm/index

E-ISSN 2580-1341 and P-ISSN 2721-0383

Accredited KEMENRISTEK/ BRIN No.148/M/KPT/2020

DOI: 10.26740/jsm.v5n1.p119-128

\title{
The Effectiveness of Google Classroom as Asynchronous Learning Media in Civics Learning
}

\author{
Tusti Setiawati $^{1 *}$, Ega Prakarsa ${ }^{2}$ \\ ${ }^{1}$ SMPN 9 Cimahi, Cimahi, Indonesia \\ Email: tusti.setiawati@gmail.com \\ ${ }^{2}$ Post Graduate Program in Sociology Education of Faculty of Social Science Education, \\ Universitas Pendidikan Indonesia, Bandung, Indonesia \\ Email: egaprakarsa@upi.edu
}

\begin{abstract}
Learning through asynchronous google classroom media is considered a learning solution during a pandemic. Unlike learning through synchronous media, the limitations of accessing technological devices such as laptops and smartphones can be overcome in asynchronous learning in google classroom. The purpose of this study is to see the effectiveness of google classroom as an asynchronous medium that is still used by teachers in Civics learning.This study uses a quantitative approach.Descriptive statistics are used to measure the distribution of respondents' responses to the research questionnaire. The questionnaire was distributed within a span of 7 days via google form and 30 teachers were selected as respondents in this study. The results of this study indicate that google classroom as an asynchronous media tends to be used by teachers and is considered effective in learning Citizenship Education (Civics). This research has implications as a scientific reference so as to encourage the extensification of e-learning learning theory, and can be used as material for evaluation and formulation of policies in the scope of learning.
\end{abstract}

Keywords: Asynchronous learning, google classroom, civic education, e-learning method

Paper type: Research paper

*Corresponding author: tusti.setiawati@gmail.com

Submited: 2021-01-27; Accepted: 2021-04-27; Published: 2021-04-28

Cite this document: Setiawati, Tusti, and Ega Prakarsa. (2021). The Effectiveness Of Google Classroom As Asynchronous Learning Media In Civics Learning. The Journal of Society and Media, 4(2), 119-128. DOI: 10.26740/jsm.v4n2.p119-128 


\section{INTRODUCTION}

Covid-19 brings a multidimensional crisis, especially in the field of education. Concerns from various parties about the new cluster of covid-19 transmission in schools, forcing various elements of education to limit interactions (Lestari dan Gunawan 2020). One of the limitations of interaction is the provision of distance learning. This type of learning builds a learning management system (LMS) using technological devices (Rabiman, Nurtanto, dan Kholifah 2020). Elearning learning methods, such as synchronous and asynchronous learning, are becoming a new trend of distance learning solutions (Brady dan Pradhan 2020).

Learning that uses synchronous and asynchronous learning media, utilizing the network as the main element of learning. Synchronous media facilitates teachers and students to interact at the same time, while asynchronous media utilizes the network as a medium for storing subject matter (Nieuwoudt 2020). Through asynchronous media, teachers and students can access the material anytime and anywhere (Amiti 2017).

Although distance learning uses media such as synchronous and asynchronous, in essence, distance learning has various kinds of obstacles (Insyiroh, Hariani, dan Mubaroq 2020). One of the main obstacles for teachers and students, they do not have devices to facilitate distance learning such as laptops and smartphones (Insyiroh et al. 2020).

Besides, internet networks are needed in e-learning (Radha, Kumar, dan Saravanakumar 2020). Meanwhile, internet network facilitation has not been evenly distributed in various parts of the region, so that distance learning has not been implemented in an inclusive and social class manner (Syah 2020).

In answering these challenges, asynchronous learning media is the most likely medium to be selected as a learning facility. Because students who do not have devices and networks can access learning materials anytime and anywhere (Supriyanto et al 2020). Teachers and students do not need to interact at the same time.

Asynchronous media is indeed a possible solution for conducting distance learning. However, this asynchronous media also has various disadvantages. The absence of interaction between teachers and students can cause misconceptions and miscommunication so that learning is not delivered optimally (Mojica-Nava, Yanguas-Rojas, dan Uribe 2020). 
Previous research has been conducted regarding synchronous and asynchronous learning. For example, research by Priyadarshini Dey and Somprakash Bandyopadhyay, namely "Blended learning to improve quality of primary education among underprivileged school children in India" shows that unequal technological support in schools affects learning achievement regardless of the socioeconomic conditions of students. However, this research does not focus on discussing how to develop asynchronous media as an alternative media that can be used (Dey dan Bandyopadhyay 2019).

Another study was conducted by Megawati Basri, Balqis Husain, Wiwin, namely "University Students' Perceptions in Implementing Asynchronous Learning During the Covid-19 Era". The results of this study indicate that google form as an asynchronous medium is still difficult to use by students who have limited internet networks (Basri, Husain, dan Modayama 2021).

In some of the studies above, it has not emphasized the main urgency of asynchronous learning, namely how the internet network is used as a medium for storing learning content. So that students and teachers can access these learning resources whenever they are able.

In addition to strengthening the variables that support the effectiveness of distance learning using google classroom, the novelty raised in this study is to see how teachers maintain google classrooms as an alternative to asynchronous media used in Civics learning. Through this novelty, it is hoped that it will be able to open an extensification of theory, not only for the provision of civic education, but also for learning other subjects through the asynchronous learning media google classroom.

\section{METHOD}

This study uses a quantitative approach. This approach was chosen to measure the perception of the sample in the population (Silalahi 2015). The population in this study were Civics teachers in Bandung, meanwhile, the sample in this study were 30 Civics teachers using asynchronous google classroom media who were selected through simple random sampling. The determination of respondents is based on the minimum limit of respondents in parametric statistics. Meanwhile, data was obtained through google form which was distributed online 
between 23-31 December 2020. Data analysis used descriptive statistics to see the average distribution of perceptions (Muhson 2006). The research questionnaire was elaborated based on Hrastinski's research "A study of asynchronous and synchronous e-learning methods discovered that each supports different purposes" (Hrastinski 2008).

The researcher then chooses the related content to be tested. Because, content related is related to how teachers organize learning, interact with students, and express ideas through asynchronous media (Hrastinski 2008). In this article, the researcher brings class VIII Civics subject matter to positive attitudes towards the Indonesian government system as one of the aspects to be analyzed.

\section{RESULTS AND DISCUSSION}

Asynchronous as a learning media. There are various options for organizing learning through asynchronous media. Such as google classroom, Whatsapp, and WEB. To see the distribution of asynchronous media used by respondents, it can be visualized as follows.

Table 1.

Asynchronous Media

\begin{tabular}{cccc}
\hline & Google Classroom & Whatsapp & WEB \\
\hline Responses & 19 & 10 & 1 \\
\hline
\end{tabular}

Based on the table above, respondents on average use google classroom in Civics learning as asynchronous media. Some teachers also use whatsApp and the web as asynchronous media.

Responses. Respondents' responses to the research questionnaire can be visualized as follows. 
Setiawati: The Effectiveness Of Google

Classroom As Asynchronous Learning

Media In Civics Learning

Table 2.

Respondent's Responses

\begin{tabular}{llcccc}
\hline \multicolumn{1}{c}{ Questionnaire Items } & $\begin{array}{c}\text { Strongly } \\
\text { Agree }\end{array}$ & Agree & Disagree & $\begin{array}{l}\text { Strongly } \\
\text { Disagree }\end{array}$ \\
\hline $\mathbf{1}$ & $\begin{array}{l}\text { Through } \\
\text { learning, I can still deliver the } \\
\text { subject matter well }\end{array}$ & $3 \%$ & $23 \%$ & $20 \%$ & $0 \%$ \\
\hline $\mathbf{2}$ & $\begin{array}{l}\text { Through } \\
\text { learning, students and I can } \\
\text { communicate, ask and answer } \\
\text { about learning content. }\end{array}$ & & & \\
\hline $\mathbf{3}$ & $\begin{array}{l}\text { Through } \\
\text { learning, I am still able to } \\
\text { express ideas or thoughts } \\
\text { related to the subject matter }\end{array}$ & & & \\
\hline
\end{tabular}

Based on the table above, statement no. 1 that Civics subject matter is still conveyed properly through asynchronous media. We can see that, on average, respondents agreed with this statement. Even though there are or some people who strongly agree or even disagree.

Meanwhile, statement no. 2 is a statement that the teacher can do the question and answer well even though through asynchronous media. Based on the responses above, the average teacher agrees to this question. Although we can have a significant number of teachers disagree with the statement.

Then, no. 3 is a statement item that teachers can still express ideas / design Civics learning even though through asynchronous media. Based on the table above, the average teacher agrees with this. There are some teachers who strongly agree or disagree at all that they can express ideas / design learning well through asynchronous media.

Teaching through asynchronous media. Respondents considered that Google classroom can still be used properly to deliver Citizenship Education subject matter.This is following the statement that lesson content can still be delivered attractively even though it is through google classroom as an asynchronous medium. This depends on how the teacher's ability to innovate and compile subject matter (Japar, Fadhilah, dan Syarifa 2020). 
Besides, google classroom as an asynchronous media used by the majority of respondents has been proven to increase students' independence in learning. There is a significant increase in increasing students' critical thinking (Zuriah 2020). This can also be influenced by the google classroom which has been seen as a formal medium in learning (Sobaih, Hasanein, dan Elnasr 2020).

Civics online learning through google classroom is still able to increase the learning participation of students (Sadiah 2020). Regarding Citizenship Education material in grade VIII on positive attitudes towards the Indonesian government system, it can also be conveyed properly through google classroom.

This is closely related to the teacher's ability to make the material more interesting. Because, through asynchronous learning media such as google classrooms, teachers must compile teaching materials properly because the network is used as a storage medium for learning materials (Brady dan Pradhan 2020).

Citizenship Education materials in grade VIII on positive attitudes towards the Indonesian government system can be arranged in such a way by utilizing various features of the google classroom. Like replying to comments, using emojis as social support, and being able to compile task plans (Wong 2020). This asynchronous media google classroom can personalize learning needs for both students and teachers (Kumar 2020).

Interaction between teacher and student through asynchronous media. The interaction between teachers and students is an important factor in learning. Without interaction, the learning process cannot be implemented. Because interaction is a reciprocal relationship that demands a response between two individuals accompanied by the same meaning and interpretation (Setiadi 2020). Communication in education is absolutely necessary to reduce the level of tension and separation between students and teachers (Bolotnikov, Imangulov, dan Gimadeev 2020).

In google classroom media, the interaction between teachers and students is carried out through a technology intermediary (Computer Mediate Communication) or CMC (Meier dan Reinecke 2020). Even though using technology intermediaries, teachers and students still interact.In fact, the presence of media can increase the connectedness of social interactions between teachers and students (Hill, Bennett, dan Hunter 2021). 
Setiawati: The Effectiveness Of Google

Classroom As Asynchronous Learning

Media In Civics Learning

Based on the findings above, the teacher can still interact well with students. The various media features of the google classroom provide convenience to respond to one another even in different time contexts and allow the development of new pedagogical structures in online learning (Sudarsana et al. 2019) (Wong 2020) (Karalis dan Raikou 2020). The existence of good interaction between teachers and students even though it is through technological media, will form a good learning environment (Daniati, Ismanto, dan Luhsasi 2020).

Express idea trough asynchronous media. Expressing ideas means how teachers can compile various innovative lessons using google classroom.The findings above show that teachers can design learning very well through the media of google classroom. Various features in google classroom allow teachers to create a good learning environment (Wong 2020) (Okmawati 2020).

The reason google classroom is widely used as an asynchronous media is correlated with its various features. Google Classroom is easy to use, saves time because it is integrated with various Google features such as formative assessments and so on. Google Classroom is also flexible, can be used for free, and has a large storage media (Wong 2020) (Zakaria et al. 2021). These various features and conveniences, support teachers to compile learning materials through google classrooms (Wong 2020) (Sholah 2020).

\section{CONCLUSION}

Google classroom as an asynchronous learning medium is effectively used in Civics learning. Through google classroom media, teachers can still innovate in designing learning and conveying subject matter well. Teachers can also interact with students. Google classroom as an asynchronous learning medium is effectively used in Civics learning. Through google classroom media, teachers can still innovate in designing learning and conveying subject matter well. Teachers also can still interact with students. 


\section{REFERENCES}

Amiti, Flora. 2017. "“Synchronous and Asynchronous E-Learning."” 141-53.

Basri, Megawati, Balqis Husain, dan Wiwin Modayama. 2021. ""University Students' Perceptions in Implementing Asynchronous Learning during Covid-19 Era"." Metathesis: Journal of English Language, Literature, and Teaching 4(3):263.

Bolotnikov, A. .., R. Sh. Imangulov, dan R. N. Gimadeev. 2020. "“Competences of Social Interaction and Their Role in the Process of Physical Education."” 114(19):632-35.

Brady, Anna K. dan Deepak Pradhan. 2020. “"Learning without Borders: Asynchronous and Distance Learning in the Age of COVID-19 and Beyond." ATS Scholar 1(3):233-42.

Daniati, Daniati, Bambang Ismanto, dan Dwi Iga Luhsasi. 2020. "Upaya Peningkatan Motivasi Dan Hasil Belajar Mahasiswa Dengan Penerapan Model Pembelajaran E-Learning Berbasis Google Classroom Pada Masa Pandemi Covid-19." Jurnal Kependidikan: Jurnal Hasil Penelitian dan Kajian Kepustakaan di Bidang Pendidikan, Pengajaran dan Pembelajaran 6(3):601.

Dey, Priyadarshini dan Somprakash Bandyopadhyay. 2019. “"Blended Learning to Improve Quality of Primary Education among Underprivileged School Children in India"." Education and Information Technologies 24(3):19952016.

Hill, Kristy, Paul Bennett, dan Rachael Hunter. 2021. “"It's Social Interaction.. but It's Not': A Qualitative Study Investigating the Psycho-Social Experience of Social Media by Individuals with a Visual Impairment"." Journal of Health Psychology.

Hrastinski, Stefan. 2008. "Asynchronous and Synchronous E-Learning."” Distributed Autonomous Robotic Systems 2:245-56.

Insyiroh, Inas Mufidatul, Ela Puji Hariani, dan Syahrul Mubaroq. 2020. "“Pendidikan Berbasis Kearifan Lokal Sebagai Solusi Menghadapi Kesenjangan Digital Dalam Kebijakan Pembelajaran Jarak Jauh Pada Masa Pandemi Di Indonesia."' Indonesian Journal of Social Development 1(1):5172.

Japar, Muhammad, Dini Nur Fadhilah, dan Syifa Syarifa. 2020. “"Pelatihan Penggunaan Google Classroom Dan Kahoot Untuk Meningkatkan Profesionalitas Guru Pendidikan Kewarganegaraan Di Era Digital.'” Jurnal Karya Abdi 4:18-27.

Karalis, Thanassis dan Natassa Raikou. 2020. "'Teaching at the Times of COVID19: Inferences and Implications for Higher Education Pedagogy."”

International Journal of Academic Research in Business and Social Sciences $10(5)$. 
Kumar, Sanjaya. 2020. "“'Impact of E-Learning Technologies in Higher Education Introduction"." journal of ideal review 21:12-18.

Lestari, Ayu Suci dan Gunawan. 2020. “"The Impact of Covid-19 Pandemic on Learning Implementation of Primary and Secondary School Levels.'” Indonesian Journal of Elementary and Childhood Education 1(2):67-68.

Meier, Adrian dan Leonard Reinecke. 2020. "“Computer-Mediated Communication, Social Media, and Mental Health: A Conceptual and Empirical Meta-Review." Communication Research.

Mojica-Nava, Eduardo, David Yanguas-Rojas, dan César A. Uribe. 2020.

"“Robust Asynchronous and Network-Independent Cooperative Learning."

Muhson, Ali. 2006. “"Teknik Analisis Kuantitatif.'” Makalah Teknik Analisis II $1-7$.

Nieuwoudt, Johanna Elizabeth. 2020. “"Investigating Synchronous and Asynchronous Class Attendance as Predictors of Academic Success in Online Education."” 36(3):15-25.

Okmawati, Mike. 2020. "“The Use of Google Classroom during Pandemic."” Journal of English Language Teaching 9(2):438.

Rabiman, Rabiman, Muhammad Nurtanto, dan Nur Kholifah. 2020. “"Design and Development E-Learning System by Learning Management System (Lms) in Vocational Education." International Journal of Scientific and Technology Research 9(1):1059-63.

Radha, R. K. Mahalakshmi, V. Sathish Kumar, dan A. R. Saravanakumar. 2020. "'E-Learning during Lockdown of Covid-19 Pandemic: A Global Perspective."' International Journal of Control and Automation 13(4):108899.

Sadiah, Hilma Halimatus. 2020. "'The Effectiveness of Civic Education Online Learning on The Learning Participation of Students in Garut." Jurnal Kreatif Online d:81-94.

Setiadi, Elly Malihah. 2020. Pengantar Ringkas Sosiologi (Pemahaman Fakta Dan Gejala Permasalahan Sosial). Jakarta: Kencana Prenada Media Group.

Sholah, Hanif Maulaniam. 2020. "“Teaching and Learning English Using Google." Jurnal Pusaka 8(1):1-12.

Silalahi, Ulber. 2015. 11 Journal of Visual Languages \& Computing Metode Penelitian Sosial Kuantitatif. 4th ed. ed. Nurul Falah Atif. Bandung: PT Refika Aditama.

Sobaih, Abu Elnasr E., Ahmed M. Hasanein, dan Ahmed E. Ab. Elnasr. 2020. "Responses to COVID-19 in Higher Education: Social Media Usage for Sustaining Formal Academic Communication in Developing Countries.'” Sustainability (Switzerland) 12(16):1-18. 
Sudarsana, I. Ketut, I. Ida Bagus Made Anggara Putra, I. Nyoman Temon Astawa, dan I. Wayan Lali Yogantara. 2019. "“The Use of Google Classroom in the Learning Process." Journal of Physics: Conference Series 1175(1).

Supriyanto, Agus et al. 2020. “"Teacher Professional Quality: Counselling Services with Technology in Pandemic Covid-19.'" Counsellia: Jurnal Bimbingan dan Konseling 10(2):176.

Syah, Rizqon H. 2020. “'Dampak Covid-19 Pada Pendidikan Di Indonesia: Sekolah, Keterampilan, Dan Proses Pembelajaran." SALAM: Jurnal Sosial dan Budaya Syar-i 7(5).

Wong, Ruth. 2020. ““'When No One Can Go to School: Does Online Learning Meet Students' Basic Learning Needs?"." Interactive Learning Environments $3: 1-17$.

Zakaria, Maheran, Faculty Accountancy, Universiti Teknologi Mara, dan Cawangan Kelantan. 2021. "Benefits and Challenges of Adopting Google Classroom in Malaysian University: Educators' Perspectives." Illkögretim Online 20(1):1296-1304.

Zuriah, Nurul. 2020. “"Strategy for Implementing Blended Learning With Google Classroom during the COVID-19 Pandemic Era in Higher Education."' Advances in Social Science, Education and Humanities Research 477(Iccd) 559-63. 